International Journal of

Emerging Multidisciplinary Research

\title{
Direct Displacement Based Seismic Design of RC Frame Structure
}

\author{
Mrinmoy Kirtania $^{1}$ and Probhakar Chakravorty ${ }^{2}$ \\ ${ }^{1,2}$ Sikkim Manipal Institute of Technology, Sikkim Manipal University, East Sikkim,737136, India
}

\begin{abstract}
Background/Objectives: In this paper we direct a seismic design of a Reinforce concrete frame building under displacement based design. Methods/Statistical analysis: There is a problem with force based design that we can't find a clear relation between forces \& cracking, that was drift or displacement is directly related with damage. Findings: By this simple design method we consider drift as parameter and can easily design this with given performance level under-code drift limit. In this paper determine maximum deviation from target drift\& justified it code limit. Improvements/Applications: The approach of our design methodology satisfactorily achieves by inelastic time history analysis as well as push over analysis. In this simple design we get a very successful and a clear predictable seismic response.
\end{abstract}

\section{Index Terms}

Seismic Design, Force \&Cracking, Target Drift, Performance level, Time History Analysis

\footnotetext{
Corresponding author: Mrinmoy Kirtania

er.mrinmoy2016@gmail.com

- Manuscript received March 18, 2018.

•Revised March 26, 2018; Accepted March 27, 2018.

-Date of publication March 31, 2018.

(c) The Academic Society of Convergence Science Inc.

2546-1583 @ 2017 IJEMR. Personal use is permitted, but republication/redistribution requires IJEMR permission.
} 


\section{INTRODUCTION}

Reinforce concrete frame structures are very regular use in a common buildings, every buildings belongs from types of seismic region. As a structural engineer we have to design a earth quake resistant design. It is hardly possible to design $100 \% \mathrm{EQ}$ resistant [1] buildings but we can easily design a safe design under some hazard level.

In past the structural designer mostly follow force based seismic design. Some researcher \& scholar may found that there is not directly relation between force and damage, that was strain or drift has a clear and effectively related with structural cracking [2]. Due to ground motion or we directly say EQ is main reason for failure of an structural frame. The researchers name this new way to design method is call Displacement Based Design, andit's very effective \& simple method. Concept of this method fully based on considering our structure as SDOF system. There is much literature available to describe this proposed design method. In this paper we satisfy our design by our Indian standard maximum code drift limit \& also care its performance level. The performance level of a building is divided [1] into three parts first one is immediate occupancy, in this level damage lowest. $2^{\text {nd }}$ one is life safety in this level and life is safe under ground motion, $3^{\text {rd }}$ one is collapse prevention here the structure is highly in damage at near collapse.

Table1.List Of Symbol And MeAning

\begin{tabular}{|c|c|}
\hline EQ & Earth Quake \\
\hline$\theta_{\mathrm{y}}$ & Yield Drift \\
\hline$\varepsilon_{\mathrm{y}}$ & Yield Strain In Rebar \\
\hline $\mathrm{L}_{\mathrm{b}}$ & Length Of Beam \\
\hline $\mathrm{h}_{\mathrm{b}}$ & Depth Of Beam \\
\hline$\Theta_{\mathrm{d}}$ & Design Drift \\
\hline$\Theta_{\mathrm{yF}}$ & Yield Rotation Of Frame \\
\hline$\Theta_{\mathrm{p}}$ & Plastic Rotation Of Frame \\
\hline $\mathrm{MDOF}$ & Multi Degree Of Freedom \\
\hline $\mathrm{SDOF}$ & Single Degree Of Freedom \\
\hline$\Delta_{\mathrm{d}}$ & Design Displacement \\
\hline $\mathrm{M}_{\mathrm{e}}$ & Evaluated Mass \\
\hline $\mathrm{H}_{\mathrm{e}}$ & Effective Height \\
\hline$\Delta_{\mathrm{c}}$ & Critical Storey Displacement \\
\hline$\delta_{\mathrm{c}}$ & Value For Critical Storey \\
\hline $\mathrm{PBD}$ & Force Based Design \\
\hline$\Delta_{\mathrm{i}}$ & Expected Target Displacement \\
\hline$\Delta_{\mathrm{y}}$ & At Each Floor \\
\hline$\mu$ & Yield Displacement \\
\hline
\end{tabular}

\begin{tabular}{|c|c|}
\hline$\xi$ & Damping Of Structure \\
\hline $\mathrm{T}_{\mathrm{e}}$ & Effective Time Period \\
\hline$K_{e}$ & Effective Stifness \\
\hline$V_{B}$ & Base Shear \\
\hline$F_{i}$ & For At Floor Level \\
\hline$F_{t}$ & $10 \%$ Of Total Base Shear \\
\hline$N T H$ & $\begin{array}{c}\text { Nonlinear Time History } \\
\text { Analysis }\end{array}$ \\
\hline$I S D$ & Inter Storey Drift \\
\hline$L S$ & Life Safety \\
\hline$C P$ & Collapse Pretension \\
\hline$I O$ & Immediate Occupancy \\
\hline$D D B D$ & $\begin{array}{c}\text { Direct Displacement Based } \\
\text { Design }\end{array}$ \\
\hline
\end{tabular}

\section{SELECTION OF TARGET DiSPLACEMENT}

\section{A. Yield displacement}

The selecting performance drift limit also call design drift, by strong column weak beam concept [1] we can say our target for local failure occur in beam first that's why we have to consider plastic rotation of beam only. If $\varepsilon y$ is yield strain in rebar [2]

$$
\theta_{y}=0.5 \varepsilon_{y} \cdot \frac{L_{b}}{h_{b}}
$$

By this equation we get the maximum angular yield rotation. The design drift of a system comes from sum of yield drift \& plastic rotation of system.

\section{B. Plastic Rotation}

We also say plastic rotation of frame comes from beam because hinges form first in Beam then Column cause of strong column weak beam concept.

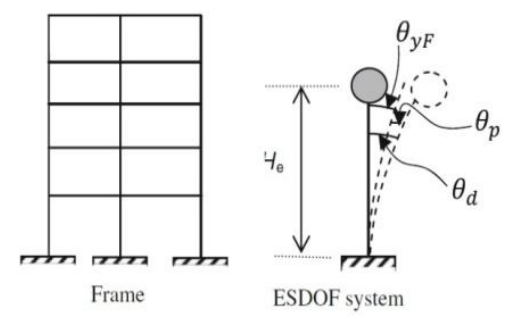

Fig.1. Allowable Design Target Displacement

$$
\theta_{d}=\theta_{y F}+\theta_{p}
$$


We can determine the plastic rotation form [3] FEMA-356.

In this paper we take our target design drift is maximum Indian standard code drift limit 4\% and determine respective base shear, and also find our performance level respective base shear for same building frame. It has been always checking that our target drift limit should not cross our code maximum allowable drift limit.

\section{DeSIGN Method}

\section{A. Pre-designed}

Our main objective of design in this method we take cares only the drift. The design methodology vastly describe in DDBD M.J.N Pristly, G.M Calvi, M.JKowalsky [1]

We have to do a preliminary design of a frame, as per demand we take a column section with predictable design steel $2 \%-3 \%$. As per recruitment respective beam size adopted from target performance level [1]. As we know yield rotation of beam depended upon $\mathrm{Lb} / \mathrm{Db} \&$ the plastic rotation of beam adopted from average plastic rotation of frame. [4] The beam depth kept from 0.33 to .5 times of beam depth.

\section{B. Convert into SDOF system}

By considering our system as SDOF we got some properties from DDBD M.J.N Pristly, G.M Calvi , M.J Kowalsky[1] we got

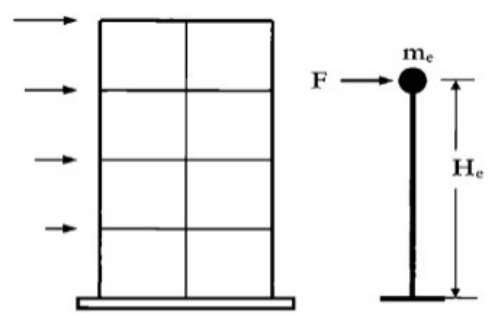

(a) SDOF Simulation

Fig. 2.MDOF to SDOF REPRESENT.

\section{Design Parameter Determination:}

Design Displacement $\left(\Delta_{d}\right)$, Equivalent Mass $\left(M_{e}\right)$, Effective Depth $\left(\mathrm{H}_{\mathrm{e}}\right)$

$$
\Delta_{d}=\frac{\sum m_{i} \Delta_{i^{2}}}{\sum m_{i} \Delta_{i}}
$$

$$
\begin{gathered}
m_{e}=\frac{\sum m_{i} \Delta_{i}}{\Delta_{d}} \\
H_{e}=\frac{\sum m_{i} \Delta_{i} h_{i}}{\sum m_{i} \Delta_{i}}
\end{gathered}
$$

From table 1 we see symbol meaning

Here mi is mass of each floor and hi height of floor $\Delta_{\mathrm{i}}$ are displacement at each floor $[5,6]$.

$$
\begin{gathered}
\delta_{i}=\frac{H_{i}}{H_{n}} \\
\text { For } n \leq 4 \\
\delta_{i}=\frac{4}{3} \cdot \frac{H_{i}}{H_{n}} \cdot\left(1-\frac{H_{i}}{4 H_{n}}\right) \\
\Delta_{i}=\delta_{i} \cdot \frac{\Delta_{c}}{\delta_{c}}
\end{gathered}
$$

\section{Damping and Ductility:}

From PBD [1] we determine system ductility \& by this we get our damping, it will bring our design to the next level. Respect to design displacement [5] and damping we find period (T) of our system

$$
\begin{aligned}
& \Delta_{y}=\theta_{Y F} H_{e} \\
& \mu=\Delta_{\mathrm{d}} / \Delta_{\mathrm{y}} \\
& \xi=5+120\left(\frac{1-\mu^{-0.5}}{\pi}\right) \%
\end{aligned}
$$

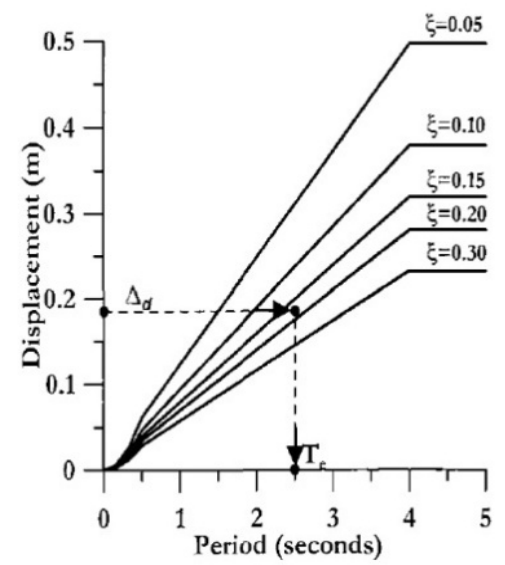

Fig. 3. Displacement and period relation respect to damping of system

\section{E. Base Shear, Stiffness, Force Distribution:}

$$
K_{e}=4 \pi^{2} \frac{m_{e}}{T_{e^{2}}}
$$


Multiplying design displacement and stiffness we also find our base shear, and force distribution at each floor[7,8].

$$
\begin{gathered}
V_{b}=K_{e} \Delta_{d} \\
F_{i}=V_{b} \frac{\Delta_{i} m_{i}}{\sum_{i}^{n} m_{i} \Delta_{i}}
\end{gathered}
$$

The base now distributed at each floor level. At roof level the total base shear $10 \%$ is add[9]

$$
F_{i}=F_{t}+V_{b} \frac{\Delta_{i} m_{i}}{\sum_{i}^{n} m_{i} \Delta_{i}}
$$

\section{METHOD APPLY ON SYMMETRICAL BUILDING}

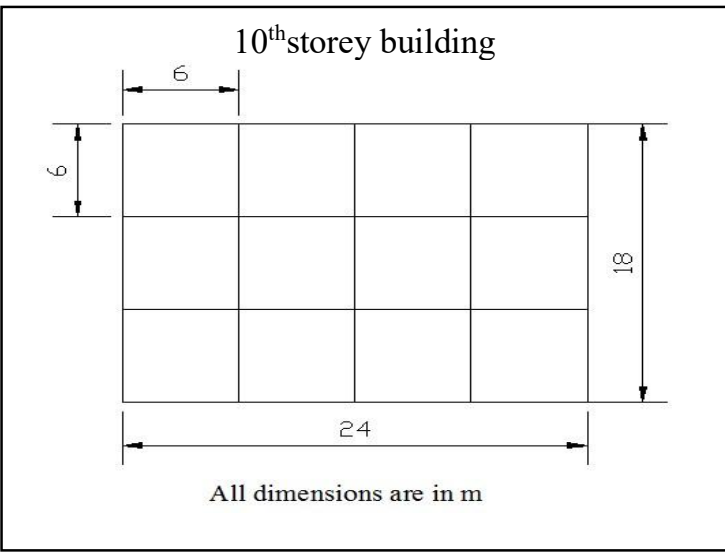

Fig. 4. $x-y$ layout of building

Table 2. CROSS SECTION DETAIL:

\begin{tabular}{|c|c|}
\hline BEAM & $650 \mathrm{MM} \mathrm{X} \mathrm{1300MM}$ \\
\hline COLUMN & $900 \mathrm{MM} \mathrm{X} \mathrm{900} \mathrm{MM}$ \\
\hline SLAB & $220 \mathrm{MM}$ \\
\hline
\end{tabular}

Table 3. PROPERTY OF MATERIAL:

\begin{tabular}{|c|c|}
\hline Concrete grade & M 20 \\
\hline Rebar grade & Fe 415 \\
\hline Strain of Rebar & 0.002 \\
\hline
\end{tabular}

Table 4. Total allowable Rotation For Performance LEVEL

\begin{tabular}{|c|c|c|c|}
\hline $\begin{array}{c}\text { Yield } \\
\text { rotation }\end{array}$ & IO & CP & LS \\
\hline 0.0046 & 0.005 & 0.01 & 0.015 \\
\hline $\begin{array}{c}\text { Total } \\
\text { rotation }\end{array}$ & 0.0096 & 0.0146 & 0.0196 \\
\hline
\end{tabular}

Table5. MASS OF STOREY

\begin{tabular}{|c|c|}
\hline n storey & $2800 \mathrm{KN}$ \\
\hline$(\mathrm{n}-1)$ storey & $3200 \mathrm{KN}$ \\
\hline
\end{tabular}

Table 6. GROUND MOTION DETAIL
\begin{tabular}{|c|c|c|c|c|c|}
\hline $\begin{array}{c}\text { Artificial } \\
\text { ground } \\
\text { motion }\end{array}$ & GM1 & GM2 & GM3 & GM4 & GM5 \\
\hline $\begin{array}{c}\text { Record } \\
\text { no }\end{array}$ & Centro & $\begin{array}{c}\text { Kobe } \\
1995\end{array}$ & $\begin{array}{c}\text { Whitte } \\
\text { r } 1987\end{array}$ & $\begin{array}{c}\text { Loma } \\
\text { Prieta }\end{array}$ & $\begin{array}{c}\text { Koccac } \\
\text { eli }\end{array}$ \\
\hline $\begin{array}{c}\text { Duration } \\
\text { (s) }\end{array}$ & 40 & 48 & 40 & 40 & 28 \\
\hline
\end{tabular}

Table 7. DDBD CALCULATED DESIGN PARAMETER:

\begin{tabular}{|c|c|c|c|c|}
\hline $\begin{array}{c}\text { Target } \\
\text { drift }\end{array}$ & Code limit & IO & LS & CP \\
\hline $\begin{array}{c}\text { Od } \\
(\%)\end{array}$ & 4 & 0.96 & 1.46 & 1.96 \\
\hline $\begin{array}{c}\Delta d \\
(\mathrm{M})\end{array}$ & 1.045 & 0.188 & 0.286 & 0.384 \\
\hline $\mathrm{Me}$ & 26032.2 & 26032.2 & 26032.2 & 26032.2 \\
\hline $\begin{array}{c}\mathrm{He} \\
(\mathrm{m})\end{array}$ & 23.6 & 23.6 & 23.6 & 23.6 \\
\hline$\mu$ & 7.18 & 1.173 & 2.62 & 3.52 \\
\hline $\begin{array}{c}\text { (eff } \\
\mathrm{Te}\end{array}$ & 28.95 & 7.93 & 19.6 & 22.84 \\
\hline $\begin{array}{c}\mathrm{Ke} \\
(\mathrm{KN} / \mathrm{M})\end{array}$ & 1522 & 60844 & 15690 & 8346 \\
\hline $\mathrm{Vb}$ & 1191.6 & 11434 & 4484 & 3202 \\
\hline \begin{tabular}{c}
$\mathrm{Vb}$ \\
\hline
\end{tabular} & 1.3 & 2.56 & 3.51 \\
\hline
\end{tabular}

\section{Justification Of Proposed Method}

In DDBD method we have to clear that a response of building only for beam sway mechanism [2], it's possible to design a soft storey but the design displacement of soft storey is very low. Now run NTH [10] analysis building and evaluated the result with our design data, both compares 


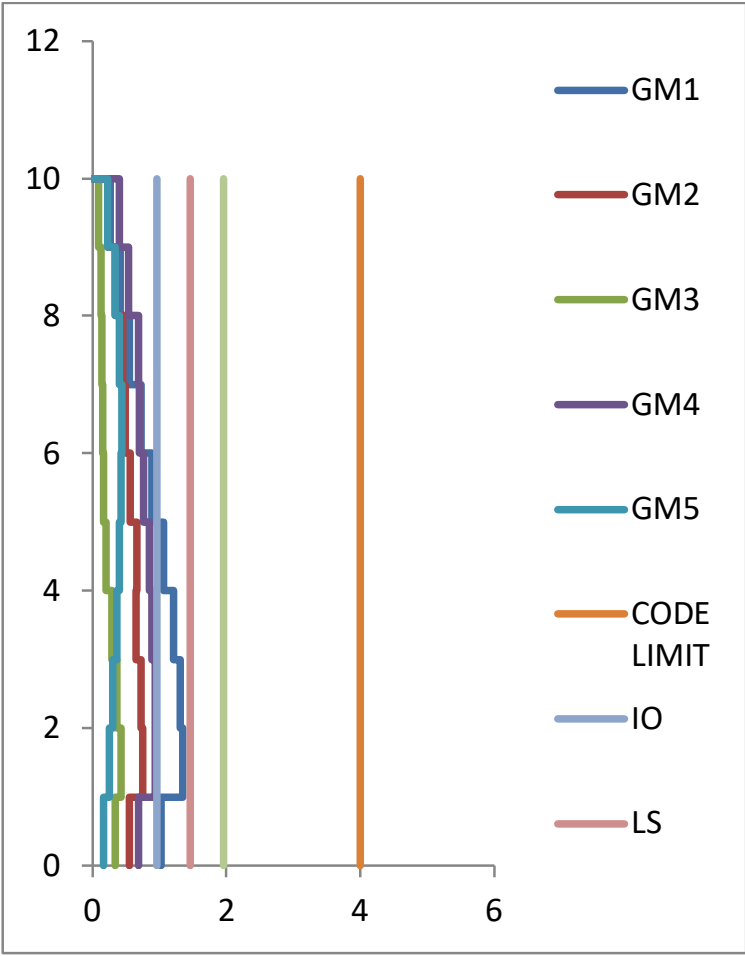

Fig. 5. Inter Storey Drift Response under Ground Motion

Due to ground motion maximum ISD found $1.024 \%$, in fig 5 that was less from LS CP level displacement that means building satisfy under this performance level. Here we compare with target drift level shear force distribution \& target displacement. Here we find that at IO level our design Base shear is maximum and we get less displacement at the same time when our RC frame response [6]. Five types ground motion detail given in table 6 .

All sectional \& material property describe in table 2 , 3 respectively. By this we got our allowable rotation given in table 4 and building mass shown in table 5 . All calculated parameters given in table 7 .

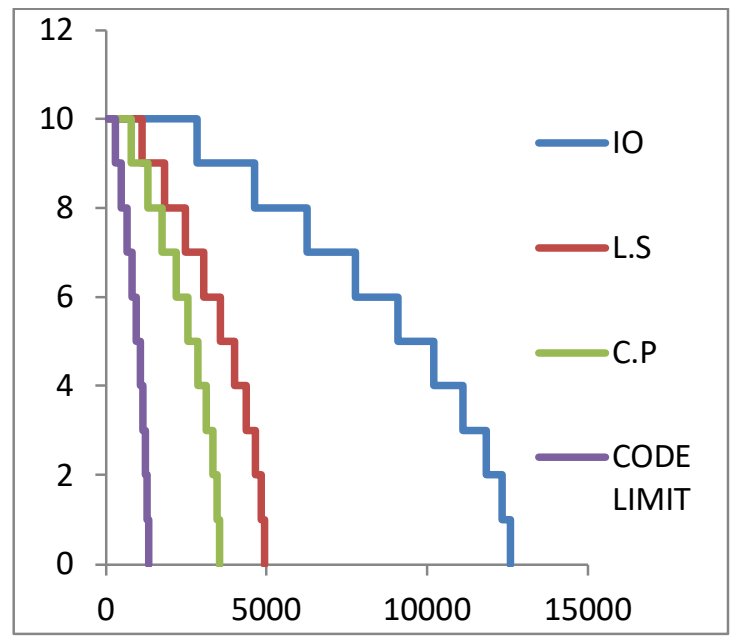

Fig. 6. Force Distribution at Floor Level

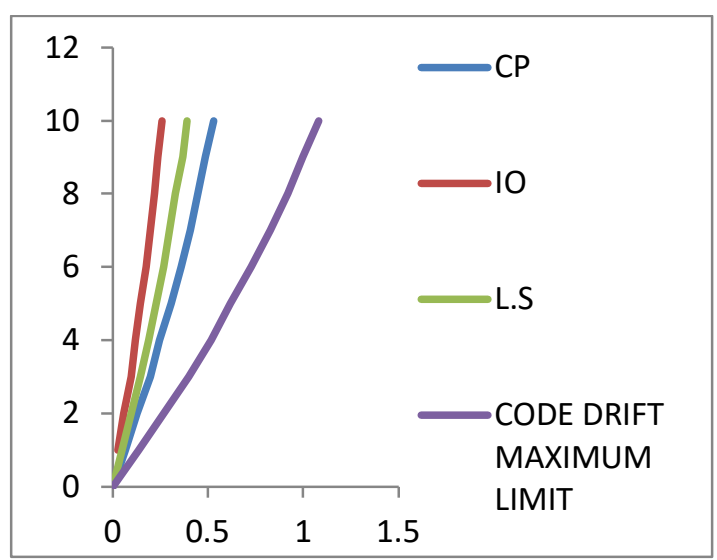

Fig. 7. Expected Displacement Profile

\section{Conclusion}

By this proposed design method has been applied to an rc frame with 10thstorey building in different performance level as well as maximum Indian Standard code drift limit. Here we conclude that analyzing our whole structure in manually by DDBD method and did a TH analysis [10] compare with our target displacement with NTH result with different hazard level we conclude that the posed method satisfy its target objective for its all member. According tobuilding impotency we have to select our objective performance level that we can design that with target performance level achieves drift[1].

\section{REFERENCES}

[1] S.choudhury, S.M.Singh (2013), A Unified Approach to Performance-Based Design of RC Frame Buildings, The Institution of Engineers (India), 94(2), 73-82.

[2] J. DidierPettinga, M.J. Nigel Priestley(2005), Dynamic Behaviour of Reinforced Concrete Frames Designed with Direct Displacement-Based Design, European school for Advance Studiesin Reduction of Seismic Risk Research Report No. ROSE-2005/02.

[3] FEMA-356, in Prestandard and Commentary for the Seismic Rehabilitation of Buildings. US Federal Emergency Management Agency, 2000.

[4] G.M.Calvi, M.J.N.Priestley, M.J.Kowalsky (2007), Displacement Based Seismic Design of Structures, IUSS Press, Pavia, $670 \mathrm{pp}$.

[5] B.Massena, R.Bento, H.Degee (2012), Assessment of Direct Displacement Based Seismic Design of Reinforced Concrete Frames, Ministry of Science and Technology of the Republic of Portugal, Research Project PTDC/ECM/100299/2008.

[6] T.J.Sullivan, M.J.N. Priestley, G.M. Calvi (2006), in Seismic Design of Frame-Wall Structures. Research Report No. ROSE-2006/02.

[7] M.J.N. Priestley(1993), in Myths and Fallacies in Earthquake Engineering. Bull.NZ. Natl. Soc. Earthq. Eng. 26(3), 329-341.

[8] J. Browning, in satisfying Performance Criteria for of Existing Concrete Buildings. Applied Geochronology Council, 1996.

[9] Q. Xue(2001), A direct displacement-based seismic design procedure of inelastic structures. Eng. Struct. 23, 1453-1460.

[10] SAP2000 v.19.1 Nonlinear, Educational Version (Computer and Structures Inc,2017). 